\title{
Pengaruh Ekstrak Etanol Daun Kemangi (Ocimum basilium) Sebagai Insektisida Terhadap Nyamuk Dengan Metode Elektrik
}

\author{
Hesti Marliza1 ${ }^{1}$ Rizka Fenida ${ }^{2}$ \\ ${ }^{1}$ Program Studi Sarjana Farmasi, Sekolah Tinggi Ilmu Kesehatan Mitra Bunda Persada, \\ Batam (29444), Kepulauan Riau, Indonesia \\ ${ }^{2}$ Program Studi Analis Kesehatan, Akademi Analis Kesehatan Putra Jaya Batam, Batam \\ (29424), Kepulauan Riau, Indonesia
}

*Hesti Marliza. 081276342515. Email: hesti79id@gmail.com.

\begin{abstract}
Abstrak
Kandungan aktif yang terdapat dalam kemangi diperkiraan dapat digunakan sebagai insektisida alternative beberapa senyawa yang ada dalam kemangi adalah eugenol dalam eugenol sendiri terdapat senyawa saponin dan flavonoid. Saponin dapat merusak kutikula nyamuk dan mengganggu sistim pernafasan pada nyamuk, sedangkan flavonoid menyebabkan permeabilitas rongga badan pada nyamuk menjadi rusak. Penelitian ini bertujuan untuk membuktikan pengaruh ekstrak etanol daun kemngi sebagai insektisida terhadap nyamuk sengan metode elektrik. Metode penelitian eksperimental dengan pendekatan post test-only control group design perlakuan dengan memberikan ekstrak etanol daun kemangi dengan konsentrasi $100 \%, 80 \%, 60 \%, 40 \%$ dan $20 \%$ terhadap nyamuk secara random dan diberi perlakuan serta ada pengontrolnya kemudian dibandingkan untuk menentukan keefektifan treatment. Dari penelitian yang telah dilakukan didapatkan hasil konsentrasi $100 \%$ menunjukkan pengaruh insektisida paling besar dengan kematian $100 \%$ selama 24 jam. Dari hasil penelitian dapat disimpulkan bahwa ekstrak etanol daun kemangi member pengaruh sebagai insektisida terhadap nyamuk dengan metode elektrik.
\end{abstract}

Kata kunci: Kemangi, nyamuk, insektisida, metode elektrik.

\section{Abstract}

The active ingredient contained in an estimated basil can be used as an alternative insecticide compounds are present in the eugenol in basil eugenol alone there are saponins and flavonoids. Saponins can damage the cuticle mosquitoes and disrupt the respiratory system in mosquitoes, while flavonoids cause the permeability of the body cavity in mosquitoes become damaged. This study aims to prove the effect of ethanol extract of leaves kemngi as an insecticide against mosquitoes sengan electrical methods. Experimental research methods to approach post-test-only control group design treatment by giving ethanol extract of basil leaves with a concentration of $100 \%, 80 \%, 60 \%, 40 \%$ and $20 \%$ against mosquitoes randomized and treated, and no controller is then compared to determine the effectiveness treatment. From the research that was done showed a concentration of $100 \%$ shows the effect of insecticides most with $100 \%$ mortality for 24 hours. From the results of this study concluded that ethanol extracts of basil leaves as a member of the effect of insecticides against mosquitoes with an electric method.

Keywords: Basil, mosquitoes, insecticides, electric methods

\section{PENDAHULUAN}

Indonesia adalah Negara yang berada di daerah tropis, sehingga merupakan daerah endemik bagi penyakit-penyakit yang diperantarai penyebarannya oleh nyamuk seperti demam berdarah, malaria, 
filariasis. Pengendalian nyamuk maupun perlindungan terhadap gigitan nyamuk merupakan usaha untuk mencegah penyebaran penyakit tersebut.

Masyarakat menyadari bahwa penggunaan insektisida secara berlebihan mengakibatkan efek negative bagi tubuh dan penggunaaan bahan kimia menimbulkan efek samping seperti. karsinogenik, merusak selsel liver (hepatotoksik), merusak system syaraf serta system reproduksi, sukar terurai oleh factor-faktor lingkungan dan bersifat resisten (Hamdani, 2004) sehingga masyarakat lebih memilih penggunaan bahan alami yang berasal dari tumbuhan Kemangi (Ocimum basillicum) merupakan salah satu tumbuhan yang bayak tersedia dan mudah diperoleh di Indonesia. Selain digunakan sebagai lalapan daun kemangi dapat digunakan sebagai obat bronchitis, asma, malaria, diare, disentri, penyakit kulit dan lain-lain. Pada daun kemangi terdapat kandungan aktif yang diperkirakan memiliki aktivitas sebagai insektisida diantaranya monoterpenoid dan eugenol, kedua senyawa ini dapat merusak mukosa kulit, menyebabkan rasa terbakar pada kulit dan mengganggu saluran pernafasan pada nyamuk dewasa (Robinson, 1995)

Metode elektrik dengan ekstrak etanol kemangi adalah salah satu jenis dari terapi komplementer. Terapi komplementer bertujuan untuk mengurangi stress, meningkatkan kesehatan, mencegah penyakit, menghindari atau meminimalkan efek samping, gejala-gejala atau mengontrol serta menyembuhkan penyakit (Purnel, 2001). Metode elektrik dipilih karena tidak menimbulkan asap dan debu serta dapat cepat dinetralisir lingkungan dibanding dengan metode semprot. Cara kerja metode elektrik ini menggunakan pembakar obat nyamuk yang didalmmnya dimasukkan gabus obat nyamuk kemudian diletakkan di kontak listrik sehingga wewangian dari gabus obat nyamuk tersebut keluar menyatu dengan udara.

\section{METODE PENELITIAN}

Jenis penelitian adalah eksperimental dengan pendekatan post test-only control group design. Perlakuan dengan pemberian ekstrak etanol daun kemangi (Ocimum basilicum) terhadap nyamuk.

Post test only control design merupakn desain yang paling sederhana dari desain eksperimental sebenarnya, kerena responden benar-benar di pilih secara random dan diberi perlakuan serta ada kelompok pengontrolnya. Pada desain ini subjek ditempatkan secara random dalam kelompok-kelompok dan di ekspose sebagai variable independen diberi post- test kemudian dibandingkan untuk menentukan keefektifan treatment

\section{Pembuatan Gabus Steril}

Gabus obat nyamuk yang ada dipanaskan dengan pemanas obat nyamuk elektrik sampai berubah menjadi putih proses ini memakan waktu sekitar 24 jam, kemudian gabus dioven selama 15 menit setelah itu gabus rendam dengan alcohol 70 \% selamat 30 menit dan rendam dengan aquadest steril selama 15 menit, kemudian oven kembali selama 20 menit gabus dinyatakan bersih jika warna benar-benar putih dan wewangian tidak tercium lagi. Kemudian gabus direndam dalam ekstrak seuai dengan konsentrasi yang ditentukan selama 24 jam gabus siap digunakan.

\section{Pembuatan Ekstrak etanol daun kemangi}

$1 \mathrm{~kg}$ daun kemangi segar dihaluskan rendam dalam $500 \mathrm{ml}$ etanol 70 \% selama 24 jam kemudian saring campuran dan si pekatkan dengan rotary evaporator hingga pelarut hilang dan didapatkan ekstrak kental. Dari ekstrak kental dibuat konsentrasi $20 \%, 40 \%, 60 \%, 80 \%$ dan $100 \%$ 


\section{Persiapan Nyamuk}

Ambil jentik nyamuk digenangan air masukkan dalam wadah yang berisi air amati perkembangan nyamuk tersebut setelah jentik berubah menjadi pupa, pindahkan pupa kedalam botol yang ditutup kain kasa kurang lebih 24 jam pupa tersebut akan berubah menjadi nyamuk

\section{Pengujian ekstrak etanol sebagai insektisida terhadap nyamuk}

Masukkan nyamuk dalam enam kelompok masing-masing kelompok berisi 20 ekor nyamuk masingmasing kelompok diberi perlakuan pemanasan gabus dengan gabus steril tanpa ekstrak kemangi, gabus dengan konsentrasi ekstrak kemangi 20 \%, 40 \%, 60 \%, 80 \% dan $100 \%$ selama 24 jam kemudian dihitung jumlah nyamuk yang mati.

\section{HASIL DAN PEMBAHASAN}

Hasil penelitian pengaruh ekstrak etanol daum kemangi dengan metode elektrik dapat dilihat pada tebel 1.

Tabel 1. Data kematian nyamuk

\begin{tabular}{cccc}
\hline No & Kelompok & Konsentrasi & Kematian \\
\hline $\mathbf{1}$ & 1 & Control (-) & - \\
$\mathbf{2}$ & 2 & $20 \%$ & 3 \\
$\mathbf{3}$ & 3 & $40 \%$ & 7 \\
$\mathbf{4}$ & 4 & $60 \%$ & 12 \\
$\mathbf{5}$ & 5 & $80 \%$ & 16 \\
$\mathbf{6}$ & 6 & $100 \%$ & 20 \\
\hline
\end{tabular}

Dari hasil penelitian didapat jumlah nyamuk yang mati pada setiap kelompok semakin meningkat seiring dengan jumlah konsentrasi ekstrak etanol yang meningkat.

\section{PEMBAHASAN}

Berdasarkan hasil penelitian diketahui ekstrak etanol daun kemangi (Ocimum basilicum) pada konsentrasi 100\% lebih berpengaruh dibanding konsentrasi lainnya. Karena ada perbedaan konsentrasi tersebut yang menyebabkan terjadinya perbedaan pada efek insektisida tiap konsentrasi ekstrak etanol. Daun kemangi mempunyai beberapa kandungan aktif yang diperkirakan memiliki aktivitas sebagai insektisida, beberapa senyawa dalam daun kemangi yaitu eugenol, didalam eugenol terdapat beberapa senyawa seperti saponin, flavonoid. Senyawa saponin dapat merusak kutikula nyamuk dan mengganggu sistem pernafasan pada nyamuk sedangkan flavonoid menyebabkan permiabilitas rongga badan pada nyamuk menjadi rusak

\section{KESIMPULAN}

Dari hasil penelitian dapat disimpulkan bahwa ekstrak etanol daun kemangi (Ocimum basilicum) yang diberikan melalui metode elektrik memiliki pengaruh sebagai insektisida terhadap nyamuk dimana ekstrak etanol dengan konsentrasi 100 \% dapat membunuh seluruh nyamuk rentang waktu 24 jam. Semakin tinggi konsentrasi ekstrak etanol daun kemangi maka semakin berpengaruh sebagai insektisida terhadap nyamuk. 


\section{DAFTAR PUSTAKA}

Chandra Budiman, 2007, Pengantar Kesehatan Lingkungan . Jakarta Buku Kedokteran-EGC

Hamdani, 2004. Insektisida Alami Ramah lingkungan : Prospek, peranan, dan Pemanfaatannya dalam PHT

Kardinan, A. 2004. Tanaman Pengusir dan Pembasmi Nyamuk, Agro Media Pustaka, Jakarta Hal 1

Robinson, T. 1995, Kandungan organic Tumbuhan Tinggi .terjemahan oleh Kosasih Padmawinata Bandung, Penerbit ITB Hal 191-192.

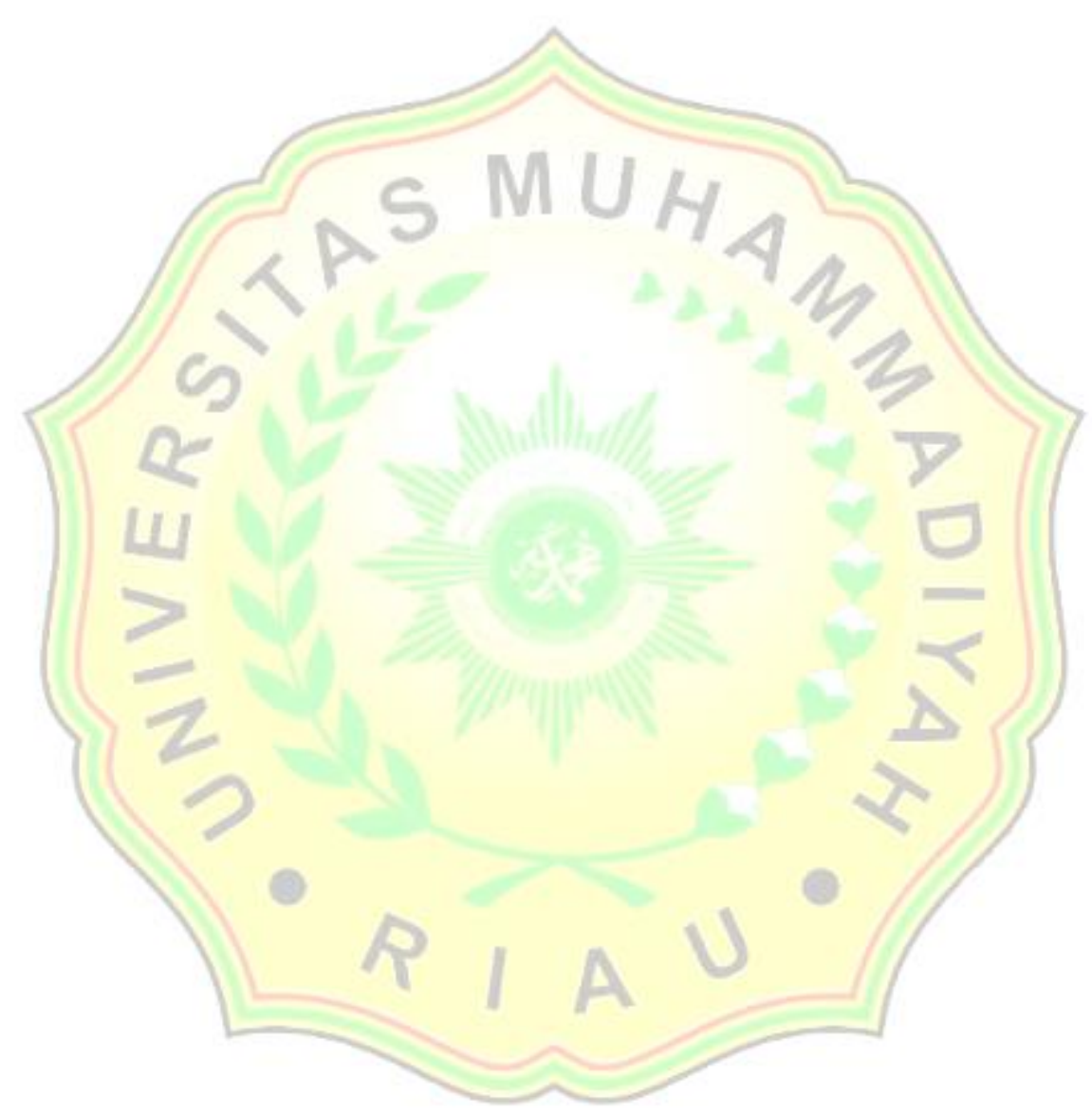

